\title{
Learning conditions for non-formal and informal workplace learning
}

\author{
Eva Kyndt, Filip Dochy and Hanne Nijs \\ Centre for Research on Teaching and Training and \\ Centre for Educational Research on Lifelong Learning and Participation, \\ Katholieke Universiteit Leuven, Leuven, Belgium
}

Learning

369

Received 16 September 2008

Revised 7 December 2008 Accepted 3 March 2009

\begin{abstract}
Purpose - The purpose of this research paper is to investigate the presence of learning conditions for non-formal and informal workplace learning in relation to the characteristics of the employee and the organisation he or she works for.

Design/methodology/approach - The questionnaire developed by Clauwaert and Van Bree on learning conditions was administered to 1,162 employees of 31 different organisations. An explorative factor analysis was performed to reduce the number of variables and to look for underlying constructs in the data. Second, a series of analyses of variance were calculated in order to be able to compare the factors in different kinds of groups of employees.

Findings - The authors concluded that for the five learning conditions that were identified in this research, different kinds of groups of employees have different chances for non-formal and informal learning. These learning conditions are "feedback and knowledge acquisition", "new learning approach and communication tools", "being coached", "coaching others", and "information acquisition".

Originality/value - The value of this research is that it has shown that characteristics of the employee and his or her organisation have a relationship with the presence of learning conditions or chances for non-formal and informal workplace learning. Moreover, this research included all kinds of employees and not only those responsible for training and education in the organisation. This research focused on conceptions and perceptions of "regular" employees.
\end{abstract}

Keywords Workplace learning, Learning, Employees

Paper type Research paper

\section{Introduction}

Over the past few decades an unprecedented rapid change in society and working life has taken place causing the importance of continuous learning to increase both for individuals operating in the learning society and for organisations competing in international markets (Tynjälä, 2008). Whereas the concept of learning used to be traditionally linked to formal education, nowadays workplace learning has gained a lot of popularity, making this field of research wide-ranged and interdisciplinary (Tynjälä, 2008). Organisations need to be able to learn and act quickly to keep up with the rapidly changing economy in order to be able to compete with other organisations (Ellström, 2001). Another change is the flexibilisation of the labour market. Employees choose to learn when they feel the need for it. Last but not least, there is the financial aspect. Learning job related skills in the workplace costs noticeably less than formal training (Boud and Garrick, 1999). Eraut (1994) states that workplace learning is more

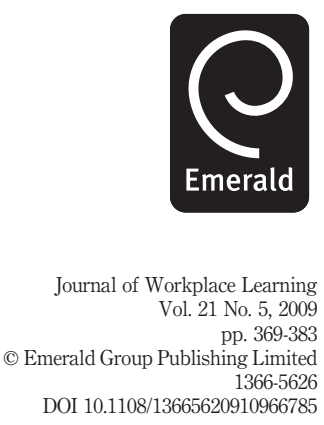


JWL 21,5

efficient than formal training when it comes to learning job-related skills and obtaining knowledge, because these specific skills and knowledge are less appreciated in formal education and the learners frequently lack the necessary insight to put theory into practice. Formal learning on its own is not sufficient to anticipate the evolutions in society since it takes too long to set it up (Baert et al., 2000).

Informal learning is described as an unplanned and implicit process with unpredictable results (Hager, 1998). This "every day" learning has a self-evident character and takes place in the daily working situation (Tjepkema, 2002; Van Biesen, 1989). It is never organised or intentional from the learner's point of view (OECD, n.d.). It is seen as the development of the individual through interaction with others (Marsick and Watkins, 1990). Informal learning often happens spontaneously and unconsciously without any a priori stated objectives in terms of learning outcomes. According to Baert et al. (2000) informal learning is an important determinant for the professionalisation of employees and organisations.

Non-formal learning consists of all education that takes place outside of the school system (Schugurensky, 2000). In contrast to informal learning, this way of learning is rather organised and can have learning objectives (OECD, n.d.). It is a way of learning where not only the content is important but where there is also a strong emphasis on practical experience (Fordham, 1993). It creates an active learning environment that no traditional teacher can accomplish. New visions are created through the discussion of, and exposure to different values, norms and ideas (Tight, 1996). Non-formal learning is seen as an individual process where the individual learns out of his/her own will (Fordham, 1993) or as a by-product of more organised activities (OECD, n.d.).

\section{Theoretical background: learning conditions}

Organisations can facilitate non-formal and informal learning by means of culture, policy and specific procedures (Marsick and Watkins, 1990). Billett (2004) states that the workplace needs to provide an optimal context for the individual to develop and grow in his job. In order to create solidarity, it is important that the affordances of the organisation match the individual engagement of the employee (Billett, 2001). After all, "while the organisation of work sets the context and conditions for learning, it is still the reciprocal interaction between the individual and the workplace that determines learning” (Tynjälä, 2008, p. 12). Tjepkema (2002) defines these learning conditions as "characteristics of the organisation and the individual that enable or hinder learning from team members” (Tjepkema, 2002, p. 111).

Learning conditions are defined as conditions created in the social, material or informational environment and in the work environment itself by key figures and agents of the labour organisation, and by the employees themselves so that other employees can learn (Clauwaert and Van Bree, 2008). The emphasis lies on conditions, possibilities or occasions created to make workplace learning possible.

Many researchers have investigated factors that could have an influence on workplace learning. These descriptive and explorative studies resulted in a variety of stimulating and obstructing conditions. In this study we focus on the stimulating conditions. Earlier research underpins the importance of several stimulating conditions. In Table I an overview is given of the learning conditions that were found to have a stimulating effect on workplace learning, a distinction was made between "context factors" and "learning factors". Context factors refer to conditions 


\begin{tabular}{|c|c|c|c|}
\hline \multicolumn{2}{|l|}{ Context factors } & \multirow{2}{*}{ Learning factors } & \multirow{2}{*}{$\begin{array}{l}\text { Learning } \\
\text { conditions }\end{array}$} \\
\hline Communication and interaction & & & \\
\hline Internal & External & Training (EDC) & \multirow{9}{*}{371} \\
\hline Meeting (EDC) & Customer contacts (EDC) & Feedback (Ashton, Ellström, Eraut, & \\
\hline Collegial consultation (EDC) & Working visits (EDC) & Onstenk, Skule, Sterck) & \\
\hline $\begin{array}{l}\text { Social work environment (Collin, } \\
\text { Eraut, Onstenk) }\end{array}$ & & $\begin{array}{l}\text { Evaluation (Collin, Elström) } \\
\text { Reflection on results (Ellström) }\end{array}$ & \\
\hline Interaction (Collin, Sterck) & & Support for learning (Ashton, & \\
\hline Participation (Collin) & & Eraut, Skule) & \\
\hline \multirow[t]{3}{*}{ Cooperation (Collin, EDC) } & & Learning potential task (Ellström) & \\
\hline & & $\begin{array}{l}\text { Challenge and value of work } \\
\text { (Eraut) }\end{array}$ & \\
\hline & & $\begin{array}{l}\text { Optimalisation learning tools } \\
\text { (Ellström) }\end{array}$ & \\
\hline Vast professional contacts (Skule) & & Confidence (Eraut) & \\
\hline Job rotation/changing shifts (EDC) & & Obligation (Eraut) & \\
\hline Possibility for change (Skule) & & Research/documentation (EDC) & \\
\hline Daily work (EDC) & & Access to knowledge and & \\
\hline Experience (Ashton) & & information (Ashton, Sterck) & \\
\hline \multicolumn{4}{|c|}{ Responsibility of governing board (Skule) } \\
\hline Question based policy (Skule) & & Supervision/mentoring (EDC) & \\
\hline Formalisation work processes (Ells & röm) & Coaching (Ellström, Sterck) & \\
\hline \multicolumn{4}{|c|}{ Rewarding skills (Skule) } \\
\hline Expectations role (Eraut) & & Performance and progress (Eraut) & \\
\hline \multicolumn{3}{|c|}{$\begin{array}{l}\text { Sources: Ashton (2004); Collin (2002); Education Development Center (1998); Ellström (2001); } \\
\text { Eraut (1994); Onstenk (1997); Skule (2004); Sterck (2004) }\end{array}$} & $\begin{array}{l}\text { Learning conditions } \\
\text { found in the literature }\end{array}$ \\
\hline
\end{tabular}

present in the context of the learner, whereas learning factors directly relate to the learning process.

The most important (general) stimulating learning conditions that were found in literature are communication and interaction (Collin, 2002; Education Development Center, 1998; Ellström, 2001; Eraut, 1994; Sterck, 2004), cooperation (Collin, 2002; Education Development Center, 1998), feedback (Ellström, 2001; Eraut, 1994; Skule, 2004; Sterck, 2004), evaluation (Collin, 2002; Ellström, 2001), participation (Collin, 2002; Ellström, 2001), reflection (Ellström, 2001), coaching (Ellström, 2001; Sterck, 2004) and information (Sterck, 2004).

\section{The present study}

This research is an extension of the research done by Clauwaert and Van Bree (2008). The purpose of their research was to find suitable indicators for non-formal and informal workplace learning to construct an instrument to map the non-formal and informal workplace learning in labour organisations. Based on literature they constructed a questionnaire that they presented to 126 human resource development (HRD) managers. These HRD managers indicated which learning conditions were actually present in the labour organisations. Clauwaert and Van Bree (2008) divided the learning conditions into six categories: work organisation, internal learning networks, external learning networks, individual learning coaching, individual work 
JWL 21,5

372 coaching and information systems. In Table II you can find the learning conditions from literature (communication, interaction, cooperation, feedback, evaluation, participation, reflection, coaching and information) linked to the six categories of the learning conditions of Clauwaert and Van Bree (2008) and their specific items. They concluded that work consultation, internet, phone and trial periods were the most common learning conditions within labour organisations in Flanders.

In this study we want to learn more about the perceptions of employees regarding the learning conditions for non-formal and informal learning and which learning conditions are present according to the employees. Moreover, we are investigating whether differences exist between different kinds of groups of employees in regard to the presence of these learning conditions.

\section{Research questions}

In this research we want to investigate the relationship between the presence of learning conditions for non-formal and informal workplace learning and some of the employee's personal characteristics, professional characteristics and characteristics of the organisation he/she is working in (see Figure 1). We formulated the following research question to address this matter:

For which groups of employees, based on their personal, professional characteristics and the characteristics of the organisation, are certain learning conditions for non-formal and informal learning, present to a higher extent in their work context?

\section{Method}

\subsection{Participants}

The participants in this study were 1,162 employees from 31 different companies and professional organisations. The sample was spread for different aspects of their profile; gender, year of birth, education, function, seniority, type of organisation or company and the size of that organisation or company (see Table III).

\subsection{Instruments}

The questionnaire on learning conditions for non-formal and informal workplace learning was developed by Clauwaert and Van Bree (2008). The questionnaire was linguistically adapted so that it could be easily understood by all, considering the different profiles. This adaption was reviewed in a pre-test by a staff member, a clerk and a worker. In this research, four questions were added to gain more insight into the learning experiences of the employees (e.g. "I'm informed on developments in my work area"). Participants were asked to score statements on a five-point Likert scale ranging from $1=$ "not agreed" to $5=$ "agree". The questionnaire could be completed in a "web based survey" or "in writing".

\subsection{Data analysis}

An explorative factor analysis was performed to reduce the number of variables and to look for underlying constructs in the data. Based on the current questionnaire, validity of the constructs and reliability of the scales were tested. First, we checked whether the data were suited for this kind of analysis. We calculated the determinant of the correlation matrix in order to rule out extreme correlations between different variables, 


\begin{tabular}{|c|c|c|c|}
\hline General learning conditions & Categories & Items & $\begin{array}{l}\text { Learming } \\
\text { conditions }\end{array}$ \\
\hline \multirow[t]{3}{*}{$\begin{array}{l}\text { Communication, interaction, } \\
\text { cooperation and participation }\end{array}$} & Work organisation & \multirow{3}{*}{$\begin{array}{l}\text { Consult other departments } \\
\text { Results of inquiries } \\
\text { Trade union meetings } \\
\text { Internal job openings } \\
\text { Job rotation } \\
\text { Common breaks } \\
\text { Work groups } \\
\text { Intervision } \\
\text { Debriefing } \\
\text { Project teams } \\
\text { Self-directing teams } \\
\text { Common rooms } \\
\text { External colleagues } \\
\text { Visit other organisations } \\
\text { Demonstrations } \\
\text { Guest speakers } \\
\text { Community of practice }\end{array}$} & 373 \\
\hline & Internal learning networks & & \\
\hline & External learning networks & & \\
\hline $\begin{array}{l}\text { Feedback, evaluation, coaching and } \\
\text { reflection }\end{array}$ & Individual learning coaching & $\begin{array}{l}\text { Personal development plan } \\
\text { Job controls } \\
\text { Walk along with colleague } \\
\text { Contact person } \\
\text { Coach } \\
\text { Internship } \\
\text { Buddy system } \\
\text { Godfather/godmother } \\
\text { Trial period } \\
\text { Mentor } \\
\text { Complex assignments } \\
\text { Feedback on functioning } \\
\text { Coach } \\
\text { Functioning consultation } \\
\text { Career consultation }\end{array}$ & \\
\hline Information & Information systems & $\begin{array}{l}\text { Knowledge of decisions } \\
\text { Job aids } \\
\text { Databases } \\
\text { Newsletter } \\
\text { Internet } \\
\text { Work e-mail address } \\
\text { Phone } \\
\text { Library } \\
\text { Log } \\
\text { TV } \\
\text { CD-ROMs } \\
\text { Idea box } \\
\text { Quality manual } \\
\text { Reports, files } \\
\text { Radio }\end{array}$ & $\begin{array}{l}\text { Table II. } \\
\text { Learning conditions, } \\
\text { categories and items }\end{array}$ \\
\hline
\end{tabular}


JWL

21,5

\section{4}

Figure 1.

Research question

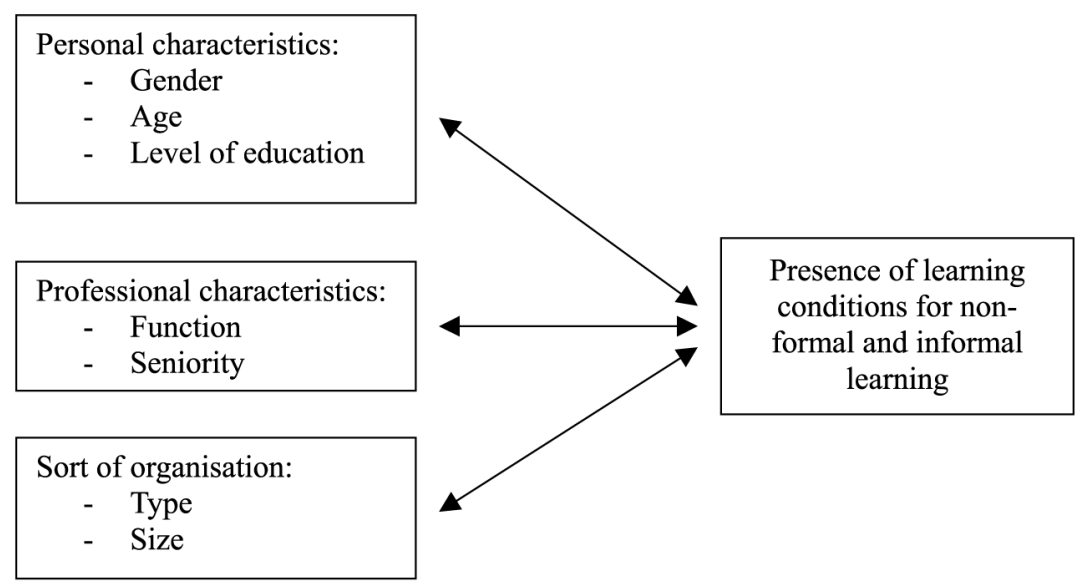

following the assumption of factor analysis that correlations among variables should be moderate. This determinant equals 0.000 , meaning that there were no extreme correlations. A Kaiser-Meyer-Olkin measure of sampling adequacy of 0.93 and a Bartlett's test of sphericity with a significance of $p<0.001$, also confirm that these data is definitely suitable for factor analysis.

Second, a series of analyses of variance (ANOVA) were calculated. We compared the newly formed factors for different characteristics of the employee or the organisation in which the employee is working. An ANOVA was performed for several characteristics: gender, age, level of education, function within the organisation, seniority, type of organisation and size of the organisation. With these analyses we hope to find significant differences between employees with different characteristics, or employees working in different kinds of organisations.

\section{Results}

First, the results of the factor analysis and the interpretation of the factors are presented. Second, the results of the different analyses of variance are presented by characteristics of the employee or the organisation in which the employee works.

\subsection{Factor analysis}

The factor analysis starts with determining the number of factors. Since the average communality is lower than $0.6(\bar{X}=0.478)$ and the number of participants is larger than 300 ( $n=1162)$, the scree plot is used to select the number of factors. Five factors were selected based on the scree plot criterium combined with the rule that every factor has to contribute at least 5 per cent of explained variance. Several items were not taken into account in the final analysis because they either did not score high on any factor or they scored high on multiple factors. In total 14 of the 59 items were not used for the final analysis. The deletion of these items led to an increase in the total amount of the explained variance.

The selected five factors of learning conditions explain 42.77 per cent of the variance. The first factor $(\alpha=0.90)$ explains 12.93 per cent. The items that load clearly on this factor concern questions about "feedback" from others (work groups, proposing 


\begin{tabular}{|c|c|c|c|}
\hline Demographic information & Number of participants & Percentage & $\begin{array}{l}\text { Learming } \\
\text { conditions }\end{array}$ \\
\hline $\begin{array}{l}\text { Gender } \\
\text { Male } \\
\text { Female }\end{array}$ & $\begin{array}{l}507 \\
655\end{array}$ & $\begin{array}{l}43.6 \\
56.4\end{array}$ & 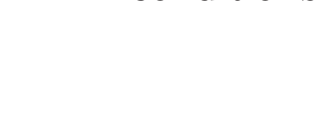 \\
\hline $\begin{array}{l}\text { Year of birth } \\
1940-1949 \\
1950-1959 \\
1960-1969 \\
1970-1979 \\
1980-1989\end{array}$ & $\begin{array}{r}38 \\
281 \\
380 \\
279 \\
180\end{array}$ & $\begin{array}{r}3.3 \\
24.3 \\
32.8 \\
24.1 \\
15.5\end{array}$ & 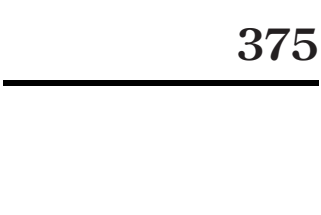 \\
\hline $\begin{array}{l}\text { Level of education } \\
\text { Master } \\
\text { Bachelor } \\
\text { Professional higher education } \\
\text { Secondary education } \\
\text { Elementary education }\end{array}$ & $\begin{array}{r}359 \\
505 \\
142 \\
131 \\
13\end{array}$ & $\begin{array}{r}31.2 \\
43.9 \\
12.3 \\
11.4 \\
1.1\end{array}$ & \\
\hline $\begin{array}{l}\text { Function } \\
\text { Workers } \\
\text { Clerks } \\
\text { Staff members } \\
\text { Other }\end{array}$ & $\begin{array}{r}179 \\
881 \\
90 \\
26\end{array}$ & $\begin{array}{r}15.6 \\
74.3 \\
7.8 \\
2.3\end{array}$ & \\
\hline $\begin{array}{l}\text { Seniority } \\
<5 \text { years } \\
5-10 \text { years } \\
>10 \text { years }\end{array}$ & $\begin{array}{l}358 \\
238 \\
560\end{array}$ & $\begin{array}{l}30.9 \\
20.5 \\
48.3\end{array}$ & \\
\hline $\begin{array}{l}\text { Type of organisation } \\
\text { Profit } \\
\text { Non-profit } \\
\text { Government }\end{array}$ & $\begin{array}{l}392 \\
395 \\
373\end{array}$ & $\begin{array}{l}33.8 \\
34.1 \\
32.2\end{array}$ & \\
\hline $\begin{array}{l}\text { Size of the organisation } \\
<20 \\
20-49 \\
50-199 \\
200-500 \\
>500\end{array}$ & $\begin{array}{l}106 \\
123 \\
342 \\
249 \\
338\end{array}$ & $\begin{array}{r}9.2 \\
10.6 \\
29.5 \\
21.5 \\
29.2\end{array}$ & $\begin{array}{r}\text { Table III. } \\
\text { Demographic information }\end{array}$ \\
\hline
\end{tabular}

ideas, debriefings, etc.) and "knowledge acquisition" (guests, speakers, results of inquiries, important decisions and assignments, etc.). The second factor $(\alpha=0.86)$ contains the items concerning "new learning approaches" (learning experiences, permanent learning, complex assignments, etc.) and items concerning the availability of "communication tools" (internet, phone and work e-mail address). This factor accounts for 9.76 per cent of the explained variance. The third factor $(\alpha=0.82)$ explains 7.92 per cent and addresses the items that involve "being coached" (contact person, buddy system, personal development plan, etc.). There is one different item among the others in this factor and that is the item concerning job rotation, however this item has the lowest loading for this factor. Factor four $(\alpha=0.78)$ concerns 
JWL 21,5

376 "coaching other employees" and tools to do this (coaching external interns, interim and voluntary employees, log, quality manual, etc.). Of the variance, 6.80 per cent is explained by factor four. The final and fifth factor $(\alpha=0.71)$ explains 5.30 per cent of the variance and includes some important items concerning "information acquisition" (library, CD-ROMs, community of practice and trade union meetings). You can find the coefficients of the items in Table IV. For interpretation purposes an overview of the factor items are given in Table V.

\subsection{ANOVA}

The different ANOVAs produced several significant differences concerning the learning factors for different groups of employees. Two learning conditions showed significant differences between the different genders. Males score significantly higher on "new learning approaches and communication tools" than females $(F=16.55$, $p<0.001)$. Males also score significantly higher for "information acquisition" than females $(F=53.71, p<0.001)$.

It was also investigated whether employees of different age groups have different opportunities for non-formal and informal learning. Significant differences were found for the three learning conditions. Employees born between 1970 and 1979 score the highest on the learning condition "feedback and knowledge acquisition", the youngest employees, born between 1980 and 1989 score the lowest $(F=7.64, p<0.001)$. There is also a significant difference when it comes to "being coached", the lowest score is obtained by the oldest group, those born between 1940-1949, whilst the highest score is obtained by the youngest group $(F=7.24, p<0.001)$. Finally, the oldest group of employees scores significantly higher on "information acquisition", the employees born between 1970 and 1979 score the lowest $(F=7.89, p<0.001)$.

Significant differences were found for employees with different levels of education for all learning conditions. The employees with a master's degree score the highest on the learning conditions "feedback and knowledge acquisition" $(F=28.97, p<0.001)$, "new learning approaches and communication tools" $(F=23.28, p<0.001)$ and "information acquisition" $(F=25.62, p<0.001)$. The lowest scores were obtained by the employees with an elementary degree. For the learning conditions "being coached" $(F=4.03, p<0.01)$ and "coaching others" $(F=11.94, p<0.001)$ employees with an elementary degree score the highest, employees with a master's degree score the lowest. It is remarkable that for all learning conditions the differences between the groups gradually increase or decrease according to an increase or decrease in level of education.

All learning conditions resulted in significant differences for employees with different functions. The highest scores on "feedback and knowledge acquisition" $(F=67.34, \quad p<0.001)$, "new learning approaches and communication tools" $(F=22.12, p<0.001)$, and "information acquisition" $(F=22.82, p<0.001)$ are obtained by staff members, the lowest scores were obtained by the workers. Workers indicate more than staff members that they are "being coached" $(F=6.14, p<0.001)$. Finally, workers score the highest on "coaching" others, the group with "other functions" scores the lowest $(F=3.97, p<0.01)$.

The seniority of the employees gives significant differences for all learning conditions, except "new learning approaches and communication tools". The highest score on "feedback and knowledge acquisition" ( $F=4.37, p<0.05)$, "coaching others" 


\begin{tabular}{|c|c|c|c|c|c|c|c|}
\hline & & & & mpon & & & conditions \\
\hline & & 1 & 2 & 3 & 4 & 5 & \\
\hline Work groups & q_1 & 0.627 & & & & & \\
\hline Propose ideas & q_2 & 0.586 & & & & & \\
\hline External colleagues & q_3 & 0.635 & & & & & \\
\hline Work consultation & q_4 & 0.591 & & & & & 377 \\
\hline Personal development plan & q_5 & & & 0.441 & & & \\
\hline Intervision & q_6 & 0.630 & & & & & \\
\hline Debriefings & q_7 & 0.477 & & & & & \\
\hline Project teams & q_8 & 0.658 & & & & & \\
\hline Visit other organisations & q_9 & 0.489 & & & & & \\
\hline Job controls & q_10 & 0.564 & & & & & \\
\hline Feedback & q_12 & 0.515 & & & & & \\
\hline Walk along with colleague & q_13 & & & 0.451 & & & \\
\hline Contact person & q_14 & & & 0.531 & & & \\
\hline To have a coach & q_17 & & & 0.615 & & & \\
\hline Guest speakers & q_19 & 0.613 & & & & & \\
\hline Results inquiries & q_20 & 0.517 & & & & & \\
\hline Knowledge of important decisions and assignments & q_21 & 0.480 & & & & & \\
\hline Buddy system & q_22 & & & 0.478 & & & \\
\hline Godfather/godmother & q_23 & & & 0.679 & & & \\
\hline Trial period & q_24 & & & 0.655 & & & \\
\hline Community of practice & q_25 & & & & & 0.519 & \\
\hline To have a mentor & q_26 & & & 0.666 & & & \\
\hline Complex assignments & q_29 & & 0.519 & & & & \\
\hline Work independently & q_30 & & 0.492 & & & & \\
\hline Trade union meetings & q_33 & & & & & 0.484 & \\
\hline Coach voluntary employees & q_34 & & & & 0.646 & & \\
\hline Coach interim employees & q_35 & & & & 0.562 & & \\
\hline Coach external interns & q_36 & & & & 0.630 & & \\
\hline Internet & q_40 & & 0.544 & & & & \\
\hline Work e-mail address & q_41 & & 0.486 & & & & \\
\hline Phone & q_42 & & 0.534 & & & & \\
\hline Library & q_44 & & & & & 0.467 & \\
\hline Log & q_45 & & & & 0.508 & & \\
\hline TV & q_46 & & & & 0.484 & & \\
\hline CD-ROMs & q_4 47 & & & & & 0.497 & \\
\hline Quality manual & q_49 & & & & 0.427 & & \\
\hline Reports on points for improvement & q_50 & 0.495 & & & & & \\
\hline Radio & q_51 & & & & 0.567 & & \\
\hline Job rotation & q_52 & & & 0.425 & & & \\
\hline Common space & q_54 & & 0.427 & & & & \\
\hline Permanent learning & q_55 & & 0.499 & & & & \\
\hline Sufficient information & q_56 & & 0.637 & & & & \\
\hline Knowledge of new developments & q_57 & & 0.665 & & & & \\
\hline Knowledge for new working situations & q_58 & & 0.683 & & & & Table IV. \\
\hline Capable of giving information about his work & q_59 & & 0.581 & & & & explorative factor \\
\hline $\begin{array}{l}\text { Notes: Extraction method: principal component an } \\
\text { Normalization; Rotation converged in eight iterations }\end{array}$ & $\begin{array}{l}\text { lysis; } \mathrm{R} \\
\text { all valu }\end{array}$ & $\begin{array}{l}\text { otation } \\
\text { les unde }\end{array}$ & $\begin{array}{l}\text { method } \\
\mathrm{r} 0.4 \mathrm{ar}\end{array}$ & $\begin{array}{l}\text { Varin } \\
\text { suppr }\end{array}$ & $\begin{array}{l}\text { x with } \\
\text { sed }\end{array}$ & Kaiser & $\begin{array}{l}\text { analysis: rotated } \\
\text { component matrix }\end{array}$ \\
\hline
\end{tabular}


JWL 21,5

\section{8}

Table V.

Overview factor items and abbreviations of the items
Factor 1: Feedback and knowledge acquisition (explained variance 12.93 per cent, $\alpha=0.90$ )

q_1 I have the chance to participate in work groups (purpose: Work groups solving production and labour problems through discussion)

q_2 I have the chance to propose my ideas on different occasions or Propose ideas forums

q_3 I have the chance to meet colleagues from another organisation External colleagues in the same working area by participating in conferences, workshops and lectures.

q_4 I have the opportunity to participate in a work consultation (consultation where tasks are divided, a planning is made ...)

q_6 I have the chance to participate in intervision moments (where different employees give their opinions and visions, share their experiences and approaches around a specific case)

q_7 I have the opportunity to look back at certain critical events or incidents and to discuss them during a debriefing

q_8 I have the chance to participate in project teams existing out of employees from different departments to work around a specific theme

q_9 I have the opportunity to visit other organizations

Work consultation

Intervision

Debriefings

Project teams

q_10 I have the chance to look into the results of job controls, audits, Job controls inspections and visitations.

q_12 I have the chance to ask for feedback about my own functioning Feedback from my colleagues, supervisors, inferiors as well as clients. $\left(=360^{\circ}\right.$ feedback, confront and make aware how people function within the organisation in the eyes of others. Making their strengths and weaknesses visible, in order to collect explicit information about his or her functioning from relevant others)

q_19 I have the chance to attend lectures of guest speakers from outside the organisations

q_20 I have the opportunity to look into and discuss the results of satisfaction- and quality inquiries from clients, patients, ...

q_21 I have knowledge of important decisions and assignments formulated by the supervisors/management

q_50 I have the chance to look into reports and files of finished projects and trainings that contain points for improvement

Guest speakers

Results inquiries

Knowledge of important decisions and assignments Reports on points for improvement

Factor 2: New learning approaches and communication tools (explained variance 9.76 per cent, $\alpha=0.86$ )

q_29 I get complex assignments appointed (assignments that challenge me, but are not too difficult)

q_30 I have the opportunity to work independently.

q_40 I can access internet and e-learning packages

q_41 I have the chance to create an own work-email address

q_42 I can use and be reached by phone

q_54 I have the opportunity to meet colleagues in a common space (office, meeting room, ...)

q_55 I learn permanently within the organisation I work

q_56 I possess sufficient information so that I can help and advice colleagues with their technical questions

q_57 I have knowledge of new developments in my working area

q_58 I have knowledge that I can apply in new working situations

q_59 I consider myself capable of giving information about this work in a comprehensive way to external persons
Complex assignments

Work independently

Internet

Work e-mail address

Phone

Common space

Permanent learning

Sufficient information

Knowledge of new

developments

Knowledge for new working situations Capable of giving information about his work (continued) 
Factor 3: Being coached (explained variance 7.92 per cent, $\alpha=0.82$ )

q_5 I am being assisted with drawing up and following up a personal development plan. (A personal development plan can be seen as a contract in which the employee and the supervisor engage themselves to accomplish certain results and development activities. It is an instrument to harmonise the demands, desires and ambitions of the individual employee and the organisation

q_13 I have the chance to walk along with a colleague at the start of their career

q_14 I have the chance to ask advice from a contact person (back office or expert)

q_17 I can have a coach

q_22 I have the opportunity to ask questions to a person who also followed the training: buddy system.

q_23 As a new employer I have/had the chance to be supported by a godfather or godmother

q_24 I have the opportunity to do a trial period in which I am accompanied

q_26 I have the opportunity to have a mentor (experienced person with the same function)

q_52 I have to opportunity to participate in a system of job rotation (changing tasks, using new and different materials and equipment, changing functions and roles)
Personal development plan

\section{Learning conditions}

379

Walk along with colleague

Contact person

To have a coach

Buddy system

Godfather/godmother

Trial period

To have a mentor

Jobrotation

$\alpha=0.78)$

Coach voluntary employees

Coach interim employees

Coach external interns

$\log$

TV

Quality manual

Radio

q_49 I have knowledge of a quality manual

q_51 There is a radio within the organisation that everybody can listen to

Factor 5: Information acquisition (explained variance 5.30 per cent, $\alpha=0.71$ )

q_25 I have the opportunity to join a learning or knowledge network Community of practice (community of practice)

q_33 I have the opportunity to attend trade union meetings

q_44 I have the chance to spend time in a library or an information Library centre (with self study packages) within the organisation

q_47 I can access CD-ROMs with basic information about the working area

CD-ROMs

Table V.

$(F=4.50, p<0.05)$ and "information acquisition" $(F=3.07, p<0.05)$ was obtained by the employees with more than ten years of seniority, the lowest score was obtained by the employees with less than five years of seniority. The employees with less than five years of seniority score the highest on "being coached", whilst the employees with more than ten years of seniority score the lowest $(F=10.74, p<0.001)$.

All learning conditions resulted in significant differences between the types of organisations. The learning conditions "feedback and knowledge acquisition" $(F=32.23, p<0.001)$, and "coaching others" $(F=14.81, p<0.001)$ occur mostly 
JWL 21,5

380 in the non-profit organisations and occur least in the profit organisations. For "new learning approaches and communication tools" $(F=9.70, p<0.001)$ and "being coached" $(F=18.21, p<0.001)$, the results are inverse, the highest score is for the profit organisations and the lowest score is for the non-profit organisations. Employees working for the government score the highest on "information acquisition", the lowest score is obtained by employees working in non-profit organisations $(F=6.04$, $p<0.01)$.

Concerning the size of the organisation all learning conditions give a significant difference. There is no unidirectional tendency however, "Feedback and knowledge acquisition" was the highest for employees in an organisation with 200-500 employees, and the lowest score for employees in an organisation of more than 500 people $(F=8.71$, $p<0.001)$. The highest score for "new learning approaches and communication tools" is obtained by employees in an organisation with less than 20 people, the lowest score is obtained by employees in an organisation with $200-500$ people $(F=24.91, p<0.001)$. "Being coached" also had the highest score for the smallest organisation, but the lowest score is obtained by the largest organisation, those with more than 500 employees $(F=11.42, p<0.001)$. "Coaching others" has the highest score for employees in an organisation with 200-500 people, the lowest score is in the largest organisations $(F=9.85, p<0.001)$. Finally, the learning condition "information acquisition" gets the highest score in organisations with 50-200 employees and the lowest score in organisations with $20-50$ people $(F=3.89, p<0.01)$.

\section{Conclusion and discussion}

We can conclude that for the five learning conditions that were identified by our research, different kinds of groups of employees have different chances for non-formal and informal learning. For every characteristic that we investigated, several significant differences were found. For the learning condition "being coached" we found some very clear differences. Generally, young employees who just started working in small non-profit organisations with an elementary degree would have more access to the learning condition "being coached" than other employees.

Another remarkable finding is the fact that when we look at the differences between the different levels of education we can see that the differences between the groups increase or decrease gradually according to an increase or decrease in level of education.

For the characteristic size of the organisation no unidirectional difference was found for the learning conditions. The results for the types of organisations are clearer. The employees in profit organisations have more access to the learning conditions "being coached", and "new learning approach and communication tools". The employees in a non-profit organisation have more access to the learning conditions "feedback and knowledge acquisition", and "coaching others". The employees working for the government have the most access to the learning condition "information acquisition". It is remarkable that employees in profit organisations have the most access to "being coached", whilst employees in non-profit organisations have the most access to the learning condition "coaching others". A more in-depth research on coaching in labour organisations might explain this apparent contradiction.

Employees with different functions are exposed to different learning conditions. It is remarkable that clerks are always situated between the staff members and the workers. Staff members have the most chances for "feedback and knowledge 
acquisition", "new learning approaches and communication tools", and "information acquisition", while workers have the least access to these learning conditions. Workers have the most access to the learning conditions "being coached" and "coaching others". Different functions require different skills and it is logical that these different skills are addressed in different ways. However, one might wonder if for example a top manager would not benefit from being coached? This research focused on the learning conditions that are present in the labour organisations, further research could investigate the needs of the employees.

There is not a lot of former research that focuses on learning conditions for non-formal and informal learning; moreover no research compared the learning conditions for different kinds of groups of employees. Therefore it is not possible to compare the results of this research with other research. Further research is needed to verify the factor structure and the differences that were found between the groups of employees.

Since all organisations participated on a voluntary basis, it is possible that these organisations do not reflect the "average" organisation regarding non-formal and informal learning. Another limitation is that the number of participants was not equal for all groups. The lower response of staff members can be attributed to the fact that they are simply less represented within labour organisations. Future research could be carried out with a larger number of staff members or with equal groups for the characteristics that are examined in the research.

This research has focused on the presence of learning conditions; however it is important to learn more about the learning effects of these conditions in order to gain more insight into the concept of workplace learning. Future research that focuses on these learning effects is needed.

\section{Implications for practice}

For practitioners and training departments, it is important to realize that in order to improve workplace learning, supporting the condition of "feedback and knowledge acquisition" contributes the most. This means that creating occasions for feedback, such as working in teams, debriefings or peer feedback are essential for employees, so do possibilities to acquire knowledge (knowledge of results of inquiries, of important decisions, of assignments, of new skills, etc.).

Further, it might be good to realize that learning conditions increase with a higher level of education of employees. As a consequence the former guideline will be more important for the low educated workers. Moreover, workers have also less access to learning conditions such as new learning approaches (e.g. permanent learning and complex assignments), communication tools (e.g. phone, internet and common space) and information acquisition (e.g. library and community of practice).

Finally, for the different types of organisations, it might be useful to focus also on the learning conditions for employees they usually do not stress: for profit organisations this means also focusing on "feedback and knowledge acquisition" and "coaching others" (e.g. coach interns, interim employees and voluntary employees). For non-profit organisations this means focussing on "being coached" (e.g. personal development plan and buddy system) and "new learning approach and communication tools" (e.g. permanent learning, knowledge of new developments and work e-mail address). 
JWL 21,5

382

\section{References}

Ashton, D.N. (2004), "The impact of organizational structure and practices on learning in the workplace", International Journal of Training and Development, Vol. 8 No. 1, pp. 43-53.

Baert, H., De Witte, K. and Sterck, G. (2000), Vorming, training en opleiding. Handboek voor een kwaliteitsvol VTO-beleid in welzijnsvoorzieningen, (Instruction, Training and Education (ITE)). Handbook for a High Quality ITE-policy in Welfare Services), Garant, Leuven.

Billett, S. (2001), "Learning through work: workplace affordances and individual engagement", Journal of Workplace Learning, Vol. 13 No. 5, pp. 209-14.

Billett, S. (2004), "Learning through work: workplace participatory practices", in Rainbird, H., Fuller, A. and Munro, A. (Eds), Workplace Learning in Context, Routledge, London, pp. 109-25.

Boud, D. and Garrick, J. (1999), Understanding Learning at Work, Routledge, London.

Clauwaert, I. and Van Bree, L. (2008), "Werkplekleren: naar een cartografie van condities voor informeel en non-formeel werkplekleren. Onderzoeksrapport Steunpunt Werk en Sociale Economie", ("Workplace learning: towards a cartography of conditions for informal and non-formal workplace learning. Research report support point work and social economy"), unpublished manuscript.

Collin, K. (2002), “Development engineers' conceptions of learning at work", Studies in Continuing Education, Vol. 24 No. 2, pp. 133-52.

Education Development Center (1998), The Teaching Firm: Where Productive Work and Learning Converge, Education Development Center, Newton, MA.

Ellström, P. (2001), "Integrating learning and work: problems and prospects", Human Resource Development Quarterly, Vol. 12 No. 4, pp. 421-35.

Eraut, M. (1994), Developing Professional Knowledge and Competence, Farmer Press, London.

Fordham, P. (1993), Informal, Non-Formal and Formal Education Programmes, YMCA, London.

Hager, P. (1998), “Understanding workplace learning: general perspectives”, in Boud, D. (Ed.), Current Issues and New Agendas in Workplace Learning, NCVER, Springfield, VA, pp. 30-42.

Marsick, V. and Watkins, K. (1990), Informal and Incidental Learning at the Workplace, Routledge, London.

Onstenk, J. (1997), Lerend leren werken. Brede vakbekwaamheid in de integratie van leren, werken en innoveren (Learning Learn Working. Broad Professional Skill in the Integration of Learning, Working and Innovating), Eburon, Delft.

Organisation for Economic Co-operation and Development (OECD) (n.d.), "Recognition of non-formal and informal learning", available at: www.oecd.org/document/25/ 0,3343,en_2649_39263238_37136921_1_1_1_37455,00.html (accessed 9 January 2009).

Schugurensky, D. (2000), "The forms of informal learning: towards a conceptualization of the field", unpublished doctoral dissertation, University of Toronto, Toronto.

Skule, S. (2004), "Learning conditions at work: a framework to understand and assess informal learning in the workplace", International Journal of Training and Development, Vol. 8 No. 1, pp. 8-20.

Sterck, G. (2004), "Leerbeleid en leerpatronen in kennisintensieve arbeidsorganisaties: concepten en praktijken", ("Learning policy and learning patterns in knowledge intensive labour organisations: concepts and practices"), unpublished doctoral dissertation, Katholieke Universiteit Leuven, Leuven.

Tight, M. (1996), Key Concepts in Adult Education and Training, Routledge, London. 
Tynjälä, P. (2008), "Perspectives into learning at the workplace”, Educational Research Review, Vol. 3 No. 2, pp. 130-54.

Tjepkema, S. (2002), The Learning Infrastructure of Self Managing Work Teams, Twente University Press, Enschede.

Van Biesen, F. (1989), "Alledaagse leren in arbeidsorganisatie (Every day learning in labour organisations)”, Ontwerp, Vol. 1 No. 1, pp. 4-11.

383

\section{About the authors}

Eva Kyndt is a PhD Student at the Centre for Research on Teaching and Training and the Centre for Educational Research on Lifelong Learning and Participation at the University of Leuven (KU Leuven), Belgium. She is doing her doctoral study on the influence of subjective workload and task complexity on student approaches to learning. Her other research interests are workplace learning and talent management. Eva Kyndt is the corresponding author and can be contacted at: Eva.Kyndt@ped.kuleuven.be

Filip Dochy is Professor of Teaching and (Corporate) Training at the Centre for Educational Research on Lifelong Learning and Participation and the Centre for Research on Teaching and Training at the University of Leuven (KU Leuven), Belgium. In his research he concentrates on new learning and training environments, new modes of assessment on teaching, and trainers' lifelong learning in teacher training and corporate training settings. He is a former president of the European Association for Research on Learning and Instruction (EARLI, www.earli.org) and editor of Educational Research Review.

Hanne Nijs obtained her masters' degree in Educational Studies at the University of Leuven (KU Leuven), Belgium. She wrote her master thesis on workplace learning.

To purchase reprints of this article please e-mail: reprints@emeraldinsight.com Or visit our web site for further details: www.emeraldinsight.com/reprints 